\title{
16. A Saturated History of Christianity and Cloth in Oceania
}

\author{
Margaret Jolly \\ The Australian National University
}

\section{Tupela i marit? ${ }^{1}$ : Christianity and cloth}

Cloth and Christianity have long been seen as intimate partners in Oceania. The introduction of manufactured cloth-cambric, ${ }^{2}$ calico, chintz, linen, serge and silk-from the mills of Manchester and New England and the workshops of China, the cultivation of the arts of sewing, quilting and embroidery and the adoption of Western-style clothing: modest dresses for women, demure trousers or laplaps for men, have all become iconic of Oceanic Christianity. Integral to the "before and after" story of indigenous conversion is the narrative of how Oceanic Christians "covered up" beautiful bare breasts, exposed bottoms or penises previously proudly displayed. In the eyes of some scholars and popular observers Oceanic people thus succumbed to the colonial power of a Western Victorian model of gender and sexuality, characterised by heterosexual monogamy, modesty and sexual repression and the celebration of a novel form of domesticity focused on the faithful wife and good mother. She was allegedly both creator and creature of a "home," bearing and nurturing children, cooking, cleaning, washing, sewing. Many scholars have challenged and complicated such stories from the perspective of Europe, North America, Africa and Asia: revealing the class, national and regional specificities in the emergence of ideals of "domesticity"; demonstrating how the realities of working women's lives differed markedly from any idealised demarcations of a masculine public sphere and a feminine domestic sphere; arguing that these spheres were leaky rather than hermetically sealed. ${ }^{3}$

\footnotetext{
1 This is a Bislama phrase which can be literally translated as "are the two married?" but which is used metaphorically to ask whether two things are conjugated. All words in Bislama, the pidgin lingua franca of Vanuatu are marked B., while those in Hawaiian are H. and those in Sa, the language of South Pentecost, S.

2 This fine, dense cloth also called batiste, was originally from Cambrai in Northern France, and was made from linen and later cotton.

3 For example see Lenore Davidoff, “Gender and the 'great divide': public and private in British gender history," Journal of Women's History 15(1) (2003): 11-27; Lenore Davidoff and Catherine Hall, Family Fortunes: Men and Women of the English Middle Class, 1780-1850, Chicago: University of Chicago Press, 1987; Julia Clancy-Smith and Frances Gouda (eds), Domesticating the Empire: Race, Gender and Family Life in French and Dutch Colonialism, Charlottesville and London: University Press of Virginia, 1998; Hyaeweol Choi, Gender and Mission Encounters in Korea: New Women, Old Ways, Berkeley and Los Angeles: University of California Press, 2009.
} 
Resonating with such critical histories of domesticity in Europe, North America and Asia, there have been several attempts to interrogate the relevance of the Western concept of domesticity in Oceania and to subvert any simple story of Christian missionaries "domesticating" Pacific women. ${ }^{4}$ Increasingly, since the early studies of Patricia Grimshaw, Christine Ward Gailey, Martha Macintyre and myself, the poignant paradoxes of the missionary project have been exposed. ${ }^{5}$ Foreign missionary women although promoting a cult of "true womanhood" hardly embodied an idealised figure of dedicated wife and mother, as Latu Latai persuasively argues for the earliest London Missionary Society couples in Samoa. ${ }^{7}$ Moreover Samoan Christians did not so much adopt these models of domesticity but, as they converted and evangelised, adapted Christianity as part of $\mathrm{fa}^{\prime}$ a Samoa. ${ }^{8}$

So too, in Vanuatu, I have argued that Christian missionary wives failed to embody the idealised figure of the wife-mother: indigenous women and girls assisted them as maids and nannies (B. haosgels); their children were often separated from them in hopes of sustaining their physical and spiritual health and purity; and they were focused on "uplifting women" not just through

4 Margaret Jolly and Martha Macintyre, "Introduction," in Family and Gender in the Pacific: Domestic Contradictions and the Colonial Impact, ed. Margaret Jolly and Martha Macintyre, Cambridge: Cambridge University Press, 1989, 1-18; Marilyn Strathern, "Domesticity and the denigration of women," in Rethinking Women's Roles in the Pacific, ed. Denise O'Brien and Sharon W. Tiffany, Berkeley: University of California Press, 1984, pp. 13-31; Holly Wardlow, Wayward Women: Sexuality and Agency in a New Guinea Society, Berkeley: University of California Press, 2006; Wardlow, "Paradoxical intimacies: the Christian creation of the Huli domestic sphere" (this volume).

5 Patricia Grimshaw, "New England missionary wives, Hawaiian women and the 'cult of true womanhood,"” Hawaiian Journal of History 19 (1985): 71-100; Grimshaw, Paths of Duty: American Missionary Wives in Nineteenth-Century Hawai'i, Honolulu: University of Hawai'i Press, 1989; Grimshaw, “New England missionary wives, Hawaiian women and the "cult of true womanhood,"' in Family and Gender in the Pacific: Domestic Contradictions and the Colonial Impact, ed. Margaret Jolly and Martha Macintyre, Cambridge: Cambridge University Press, 1989, pp. 19-44, updated version of 1985; Christine Ward Gailey, Kinship to Kingship: Gender, Hierarchy and State Formation in the Tongan Islands, Austin, Texas: University of Texas Press, 1987; Margaret Jolly and Martha Macintyre (eds), Family and Gender in the Pacific: Domestic Contradictions and the Colonial Impact, Cambridge: Cambridge University Press, 1989; Margaret Jolly, "'To save the girls for brighter and better lives': Presbyterian missions and women in the south of Vanuatu: 1848-1870," The Journal of Pacific History 26(1) (1991): 27-48; Jolly, "Divided mothers: changing global inequalities of 'nature' and 'nurture,"' in The Globalization of Motherhood: Deconstructions and Reconstructions of Biology and Care, ed. Jane Maree Maher and Wendy Chavkin, London and New York: Routledge, 2010, pp. 154-79; Latu Latai, "Changing covenants in Samoa?: From Brothers and Sisters to Husbands and Wives?" forthcoming in Gender and Person in Oceania, ed. Anna-Karina Hermkens, Rachel Morgain and John Taylor, Oceania Special Issue, projected March 2015; Latai, "From open fale to mission houses: negotiating the boundaries of "domesticity" in Samoa" (this volume).

6 Grimshaw, "New England missionary wives, Hawaiian women and the 'cult of true womanhood."”

7 Latai, "Changing covenants in Samoa"; Latai, "From open fale to mission houses," (this volume).

8 See Latai, "From open fale to mission houses," (this volume); and Latai, "Changing covenants in Samoa"; contra Gailey, Kinship to Kingship (for Tonga). See also Serge Tcherkézoff, “'On cloth, gifts and nudity' regarding some European misunderstandings during early encounters in Polynesia," in Clothing the Pacific, ed. Chloë Colchester, Oxford and New York: Berg, 2003, pp. 51-75; Tcherkézoff, "Culture, nation, society: secondary change and fundamental transformation in Western Samoa: towards a model for the study of cultural dynamics," in The Changing South Pacific: Identities and Transformations, ed. Serge Tcherkézoff and Françoise Douaire-Marsaudon, Canberra: Pandanus Books, 2005, pp. 245-301. 
classes in domesticity but through literacy and education towards the vocations of teaching and nursing. ${ }^{9}$ Moreover, although Christian missionaries and indigenous converts early transformed patterns of gendered segregation of men's houses and domestic dwellings and ended male initiations and ancestral cults, extended patterns of kinship, rather than nucleated families, perdured and Christian women continued to work hard gardening tubers, nurturing pigs, hauling wood and water, and plaiting pandanus alongside the "domestic" work of child care, cleaning, cooking, sewing and washing clothes. ${ }^{10}$

In this chapter I explore the domestic paradoxes of the missionary project by concentrating attention not on foreign missionary women but on indigenous women converts. I hope to further unsettle the simple story of the Christian "domestication" of Pacific women by looking at that icon of conversion: cloth. Through scrutinising the materiality of cloth, its threads and textures, its colours and patterns we can weave a far more interesting and nuanced narrative about Christianity and domesticity in Oceania. I highlight three threads in this narrative.

First, I stress how introduced cloth was related to several pre-existing textile traditions across Oceania - felted barkcloth (tapa/kapa), plaited pandanus and a myriad of other fibres including flax, banana leaves, bush lianas, bog irises and feathers. These cloths, typically created by women (but sometimes dyed or decorated by men), were variously used for clothing, bedding and baskets and most importantly as valuables in gift exchanges linked to life-cycle rituals or ceremonies to celebrate or elevate rank. The diverse histories of how making indigenous cloth was abandoned and later revived, moved from quotidian to episodic ritual use, was creolised and layered with introduced cloth are fascinating and complex. ${ }^{11}$ In earlier writing, I have explored transformations in

9 Jolly, “To save the girls for brighter and better lives'”; Jolly, "Divided mothers: changing global inequalities of 'nature' and 'nurture."'

10 Margaret Jolly Women of the Place: Kastom, Colonialism and Gender in Vanuatu, Chur and Reading: Harwood Publishers, 1994; Jolly, "Divided mothers: changing global inequalities of 'nature' and 'nurture"”; Jolly, "Material and immaterial relations: gender, rank and Christianity in Vanuatu," in The Scope of Anthropology, ed. Laurent Dousset and Serge Tcherkézoff, Oxford: Berghahn, 2012, pp. 110-54.

11 I prefer to use this word, analogous with its use in studies of language rather than "hybridity" which is the concept deployed in a special issue of Pacific Arts. See Ping Ann Addo, Heather E. Young-Leslie and Phyllis Herda (eds), Hybrid Textiles: Pragmatic Creativity and Authentic Innovations in Pacific Cloth, Special Issue in Honor of Jehanne Teilhet-Fisk, New Series, 3-5, 2007. Yet several contributors to that volume including Herda and Kamehiro critique the term. Like Kamehiro I think hybridity carries many racial and racist associations and that it locks interpretation into organicised models and binaries rather than more fluid processes of translation and power. It is paradoxical that it became so popular in some postcolonial celebrations of multiculturalism. See Pnina Werbner, "The limits of cultural hybridity: on ritual monsters, poetic license and contested postcolonial purifications," Journal of the Royal Anthropological Institute New Series 7 (2001): 133-52. 
several indigenous forms of cloth: doba in the Trobriand Islands, bilums in Papua New Guinea, and pandanus textiles and barkcloth across much of Oceania. ${ }^{12}$ Here I focus on introduced cloth.

Second, the adoption of introduced cloth and clothing was not simply a colonial imposition by foreign missionaries on passive Oceanic peoples, a repressive disciplining of the savage bodies of the heathens. ${ }^{13}$ Without denying the semiotic chainmail which linked nakedness, sexuality and sin in Christian conceptions, we need to acknowledge how introduced cloth was actively sought by Oceanic peoples; its very materiality a sign of the spiritual efficacy and power of foreigners. Fervent desire for foreign fabrics can be seen on early exploratory voyages; for example during Cook's three voyages (1768-1779). Oceanic peoples from Tahiti to Vanuatu (Cook's "New Hebrides") enthusiastically exchanged food and artefacts for soft sheets and crimson comforters, fabrics of lustrous beauty and sensuous efficacy and emblems of mana or divine power. ${ }^{14}$ Greg Dening relates the wonderful story of how the red British naval flag with which Tobias Furneaux had taken "possession" of Tahiti in 1767 was woven by Tahitians into the sacred red and yellow feather belt used in the installation of high chiefs, a symbol of indigenous sovereignty. ${ }^{15}$ The imbrication of the material and spiritual potency of the foreigners was perhaps even more obvious in the early stages of Christian conversion. Converts eagerly appropriated, wore and fashioned this new cloth as a sign of their adherence to this new God whose power eclipsed that of ancestral spirits and indigenous deities. Indigenous alacrity for introduced cloth is pervasive across Oceania attested not just in the fabrication of modest, modern clothing (such as the "Mother Hubbard"16 or island dress) but in innovative and creative textile arts such as the tivaevae/ tifaifai of the Cook Islands and Tahiti and the Hawaiian quilt. ${ }^{17}$

Third, the dominant forms and the hegemonic meanings of introduced cloth were dramatically transformed in such appropriations by Oceanic women. They were not just materials for and signs of cosy domesticity and Christian modernity.

12 Margaret Jolly, "Of the same cloth: Oceanic anthropologies of gender, textiles and Christianities," invited distinguished keynote lecture for the Association of Social Anthropology in Oceania, Canberra: The Australian National University, 14 February 2008. See also, Anna-Karina Hermkens and Katherine Lepani's edited collection on Women's Wealth in preparation.

13 Richard Eves, "Colonialism, corporeality and character: Methodist missions and the refashioning of bodies in the Pacific," History and Anthropology 10(1) (1996): 85-138.

14 See Jennifer Newell, Trading Nature: Tahitians, Europeans and Ecological Exchange, Honolulu: University of Hawai'i Press, 2011.

15 Greg Dening, "Looking across the beach - both ways," in Discovering Cook's Collections, ed. Michelle Hetherington and Howard Morphy, Canberra: National Museum of Australia Press, 2009, pp. 11-24, p. 16.

16 Mother Hubbard refers to a comic character in an English nursery rhyme from 1805. The link to the dress form is obscure, as is the reference to a form of camelback locomotive.

17 See my paper, "Matisse between North Africa and Oceania: Orientalism, Modernism and Métissage," for a discussion of the influence of Tahitian tifaifai made by women on Matisse's late works, Oceania the Sea and Oceania the Sky. Being revised for journal submission. 
They were and are fabrics saturated with the values of indigenous sanctity and rank, anti-colonial resistance, cultural pride, women's collectivities, national identities and transnational connections in an increasingly globalised world.

I now trace these three interwoven threads through two exemplary fabrics which have both been the subject of much recent scholarly reflection and popular debate: the Hawaiian quilt and the "island dress" of Vanuatu. Hawai'i and Vanuatu are very different Oceanic archipelagos, typically segregated by the culture area labels inherited from Dumont d'Urville: Polynesia and Melanesia. ${ }^{18}$ Despite the dubious, racial origin of such enduring distinctions, there were important indigenous differences between these island groups in the situation of women and the salience of hereditary rank, and in how the Hawaiian islands were united by a common language before their unification as a kingdom whereas Vanuatu was characterised by extreme cultural and linguistic diversity (110 indigenous languages are still extant). Both archipelagoes were subject to intense and contesting colonial influences from the early nineteenth century, in Hawai'i, primarily British and American, in Vanuatu, British and French. In Hawai'i, the indigenous monarchy was overthrown in 1893 by a cartel which combined American missionary and mercantile interests. The islands were annexed by the United States in 1898, declared a state in 1959, and despite strenuous struggles for indigenous sovereignty, remain so today. Vanuatu was subject to the conjoint control of a British and French condominium from 1906-1980 (as New Hebrides/ Nouvelles-Hébrides) in which colonial agents were far more divided by diverse metropolitan interests in land, labour and Christian missions. Vanuatu became an independent state in 1980 despite French-backed secessionist movements on Tanna and Santo. Despite these differences of indigenous culture and colonial history, there are striking affinities in the histories of Christianity and cloth, as exemplified in the Hawaiian quilt and island dress.

\section{The Hawailan quilt}

The history of the Hawaiian quilt is typically traced back to an originary moment in April 1820 when Protestant missionary couples of the American Board of Commissioners for Foreign Missions (ABCFM) arrived in Honolulu on board the brig Thaddeus. They were warmly welcomed by high-ranking Hawaiians, including four women of high rank, two widows of King Kamehameha, the ali'i nui (high chief) who had united the islands in one

18 See Margaret Jolly, "Women of the east, women of the west: region and race, gender and sexuality on Cook's voyages," in The Atlantic World in the Antipodes, ed. Kate Fullagar, Newcastle: Cambridge Scholars Press, 2012, pp. 2-32. 
kingdom ca. 1795, and the wives of two of his senior advisors. The interaction between the missionary wives and these Kanaka Māoli women was recorded by Lucy Thurston in her memoirs:

MONDAY morning, April 3d, the first sewing circle was formed that the sun ever looked down upon in His Hawaiian realm. Kalakua, queendowager was directress. She requested all the seven white ladies to take seats with them on the mats, on the deck of the Thaddeus. Mrs. Holman and Mrs. Ruggles were executive officers to ply the scissors and prepare the work. The four native women of distinction were furnished with calico patchwork to sew, - a new employment to them. ${ }^{19}$

Because of the reference to patchwork, this oft-quoted passage is frequently deemed to be the moment when Hawaiian women were taught to quilt. Yet, as Phyllis Herda suggests it was likely a far more modest sewing lesson, since "patches" at that time referred to small pieces of fabric used to instruct novices on how to use a needle and thread. ${ }^{20}$ And, as Herda observes, the broader textual and discursive context makes it plain that the first cloth sought to be fashioned was not a complicated quilt but a modest dress. The sentences in Thurston's memoir immediately preceding this passage tell us that "Kalakua brought a web of white cambric to have a dress made for herself in the fashion of those of our ladies, and was very particular in her wish to have it finished while sailing along the western side of the island before reaching the king." ${ }^{21}$ The sentences immediately following describe the Queen's dress:

The dress was made in the fashion of 1819. The length of the skirt accorded with Brigham Young's rule to his Mormon damsels, - have it come down to the tops of the shoes. But in the queen's case, where the shoes were wanting, the bare feet cropped out very prominently [emphasis in original]. ${ }^{22}$

Kalakua's keen desire to wear the new fashions from New England were no doubt matched by the fervent enthusiasm of the missionary wives that Hawaiian women of all ranks cover their bodies with something less revealing than barkcloth (even if like many missionary women they were inclined to searing satire at the expense of Kanaka Māoli when they wore their new clothes

19 Lucy G. Thurston, Life and Times of Mrs. Lucy G. Thurston. Wife of Rev. Asa Thurston, Pioneer Missionary to the Sandwich islands, Gathered from Letters and Journals Extending Over a Period of More than Fifty Years, $3^{\text {rd }}$ edition, Ann Arbor/Honolulu: S.C. Andrews/The Friend, [1882] 1934, p. 32.

20 Phyllis Herda, "Hybrid identities and the transference of Hawaiian quilt imagery," in Hybrid Textiles: Pragmatic Creativity and Authentic Innovation in Pacific Cloth. Pacific Arts, ed. Ping Ann Addo, Heather Young Leslie and Phyllis Herda, Special Issue in Honor of Jehanne Teilhet-Fisk, New Series, 3-5, 2007, pp. 37-45.

21 Thurston, Life and Times of Mrs Lucy G. Thurston, p. 32.

22 Ibid., pp. 32-33. 
ineptly). ${ }^{23}$ As Grimshaw, Herda and others insist, the missionaries equated Hawaiian "nudity" with spiritual depravity ${ }^{24}$ (but see Tcherkézoff on Tahiti and Samoa). ${ }^{25}$ This is patent in Bingham's quotation from another missionary wife who ran in startled horror to her cabin with the words:

O, my sisters, you cannot tell how the sight of these poor degraded creatures, both literally and spiritually naked, would affect you! I say naked. They have nothing but a narrow strip, which they term a marrow, tied around them. ${ }^{26}$

Although covering the nakedness of Kanaka Māoli was doubtless urgent, teaching Hawaiian women to quilt would, as Herda adjudges, hardly have been a priority in the balmy climate of islands far removed from the cold winters of the eastern United States. ${ }^{27}$ Yet quilting soon became central in the social interaction between high-ranking Kanaka Māoli women and foreign missionary wives, and in the creolisation of indigenous and introduced textiles. ${ }^{28}$

Lucy Thurston may have thought this was the first "sewing circle" in God's Hawaiian realm but Hawaiian women had long collaborated in the collective creation of indigenous textiles: barkcloth $(\mathrm{H}$. kapa), pandanus $(\mathrm{H}$. lauholo, makaloa) and featherwork (H. ahu'ula, mahiole). This was similarly stratified by rank. ${ }^{29}$ Although all women made barkcloth from the paper mulberry tree only high-ranking women of the ali'i nui (H.) class had the prerogative to make fine, decorated barkcloth. Women were responsible for creating the brilliant red and yellow feather cloaks, capes and helmets worn by male high chiefs, which figured so prominently in early Western paintings of Hawai'i and in museum collections of Oceanic things. ${ }^{30}$

\footnotetext{
23 See Jolly, "“To save the girls for brighter and better lives."”

24 Grimshaw, Paths of Duty; Grimshaw, "New England missionary wives"; Herda, "Hybrid identities and the transference of Hawaiian quilt imagery."

25 Tcherkézoff, "On cloths, gifts and nudity."

26 A maro was a waistband of tapa. Bingham quoted in Grimshaw, Paths of Duty, pp. 26-27.

27 Herda, "Hybrid identities and the transference of Hawaiian quilt imagery."

28 Stacey L. Kamehiro, "Women, quilts and chiefly aesthetics: self-representation in nineteenth-century Hawai'i," M.A. thesis in Art History, University of California at Los Angeles, 1991.

29 Herda, "Hybrid identities and the transference of Hawaiian quilt imagery"; Stacey Kamehiro, "Hawaiian quilts: chiefly self-representation in $19^{\text {th }}$ century Hawai'i," in Hybrid Textiles: Pragmatic Creativity and Authentic Innovation in Pacific Cloth. Pacific Arts, Special Issue in Honor of Jehanne Teilhet-Fisk, ed. Ping Ann Addo, Heather Young Leslie and Phyllis Herda, New Series, 3-5, 2007, pp. 23-36.

30 Commoner men and women were involved in the collection of the feathers but only women fabricated them according to Jocelyn Linnekin, "Who made the feather cloaks? A problem in Hawaiian gender relations," Journal of the Polynesian Society 97 (1988): 265-80; Adrienne Kaeppler (ed.), James Cook and the Exploration of the Pacific London: Thames and Hudson, 2009, pp. 250-51, for Adrienne Kaeppler's recent appraisal.
} 


\section{Kapa: The intimate affinity of barkcloth and quilts}

In the Hawaiian language, kapa denotes both barkcloth and quilts. As Stacey Kamehiro has so consummately argued their linguistic identification is mirrored in myriad ways: in material, formal design properties, in their uses and in the meanings and values which saturate the cloth. ${ }^{31}$ The best Hawaiian barkcloth was soft like linen; its felted fibres sometimes resembled lace. Barkcloth such as the kapa moe (H.) used for bedding was layered; several undecorated sheets were covered by a decorated top sheet, which had both a textured watermark design beaten into its surface and a design applied centrally and to the borders. They were often filled with fern mulch, pulu (H.), as batting. Quilts similarly had several conjoined layers, were filled with hair or padding and the top layer was decorated with distinctive designs, stitching and embroidery, which secured the layers together.

Both barkcloth and Hawaiian quilts are described in very similar terms, using an aesthetic imagery drawn from the legendary origins of the paper mulberry tree which grew from the body of the ancestor Maikoha, beside a flowing stream where the land met water. The underside of both barkcloth and quilt is pili (H.) that which clings to the body of a person, the upper surface is kahua (H.) the "ground," while the pulu (H.) is the moist space between, akin to the soft ground where land meets water. On a canonical Hawaiian quilt, the rows of patterns, of stitches and embroidery from centre to the edges are perceived as a series of breaking waves as they approach the "shore," the borders of the cloth.

From the 1820s New England missionary women taught high-ranking Hawaiian women the art of quilting in sewing circles in their homes and from 1830 in mission schools. They hoped that thereby all Hawaiian women would learn the art, but chiefly women maintained a monopoly not just on the art of quilting but the materials of sewing: thread, needles, thimbles and cloth. This perpetuated the dominance chiefly women had earlier attained in controlling the import of foreign goods not just vis-à-vis low-ranking women, but vis-à-vis chiefly men. ${ }^{32}$ High-ranking women had been prominent in early conversions to Christianity; indeed several had urged the overthrow of the kapu (H.) of the ancestral religion in 1819. This had forbidden men and women from eating together, had proscribed women from eating some delicious foods (including pork, coconut and banana) and from engaging in certain activities such as deep sea fishing, canoe building and war. ${ }^{33}$ These divine taboos had already been

\footnotetext{
31 Kamehiro, "Hawaiian quilts."

32 Ibid.

33 Caroline Ralston, "Changes in the lives of ordinary women in early post-contact Hawaii," in Family and Gender in the Pacific: Domestic Contradictions and the Colonial Impact, ed. Margaret Jolly and Martha 
eroded by the seeming immunity of foreign men such as those on Cook's third voyage who infringed kapu by eating with women, survived the experience and were thus credited with extraordinary mana (H. divine power). ${ }^{34}$ Unlike Cook's Resolution, the ABCFM missionary ship Thaddeus had landed not just foreign missionary men but women. High-ranking Hawaiian women forged an early alliance with these Christian women from New England but also challenged their mana, through the materiality of their quilts (Figure 36).

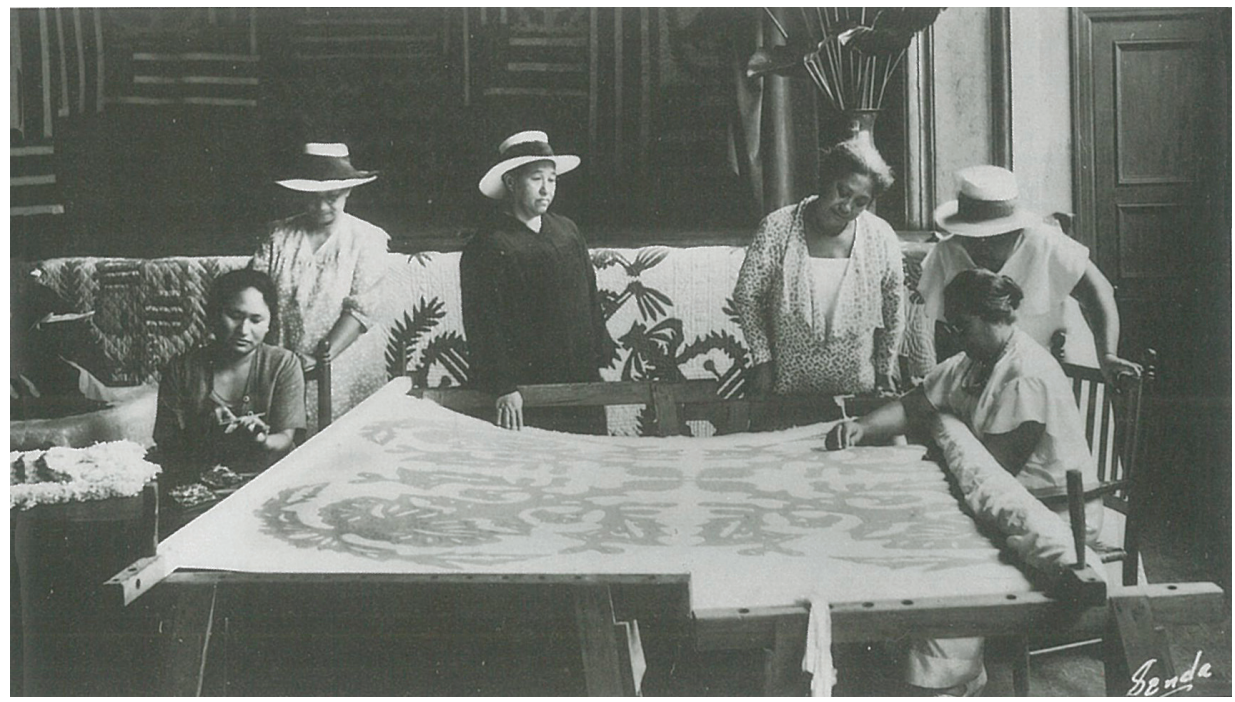

Figure 36. Left to right at the quilting horses: Adelaide Gifford carding wool; Mrs. Milia Kaiawe, Mrs. Leialoha Kanoho, Mrs. Akao Lock, Mrs. Louisa Malina, Mrs. Kalei Montgomery, working collectively on an appliqué quilt, 1933.

Source: Senda Photos, "Mokihana Club 1933 Exhibit," in Robert J. Schlek, The Wilcox Quilts in Hawaii, photographs by Hugo de Vries, Kauai, Hawaii: Grove Farm Homestead and Wailoi Mission House, 1986. Courtesy of Kaua'i Museum.

The distinctive "Hawaiian quilt," a layered appliqué quilt which emerged in the 1840 s-1860s is radically different from the American prototypes not just in form and design but in meanings and values. The dominant form of quilt made by New England missionary women was "patchwork" or "piecework," composed of many small pieces of diverse fabrics sewn together to make an overall design of harmonious colour and pattern, usually of rectilinear forms such as triangles or hexagons. In collections of early quilts made by Kanaka Māoli women (called H. kapa pohopoho) the influences of New England piecework (patchwork) are obvious but so are the transformations. American design blocks were used but

34 I cannot here enter into the very complex debate between Marshall Sahlins and Gananath Obeyesekere as to whether and how Hawaiians identified Cook as a manifestation of the god Lono. 
were invested with local meanings: e.g. the bear's paw became human fingers; the "drunkard's path" the "coconut knife." ${ }^{\prime 35}$ Some more abstract, geometric designs replicated both New England models (like the "Log Cabin") and earlier kapa patterns, indented on barkcloth with beaters, such as the zig-zag patterns of "Bent Knee." Such geometric patchwork patterns were used on some very famous quilts such as that attributed to Princess Bernice Pauahi Bishop and two which were laid on the floor of the Honolulu Catholic Cathedral in 1866 in a funerary mass on the occasion of the death of Spain's King Alphonso. ${ }^{36}$

In Hawai'i, New England piecework forms were soon surpassed by an appliqué technique. This involved folding a single piece of fabric into eight parts and then cutting a design so that either four or eight identical motifs were created in a symmetrical pattern. The source of this innovative technique is disputed. Some see it as inspired by the "snow flake" cutting of paper, popular as a pastime for Euro-American children in this period. Some see it as practical indigenous innovation: "to cut new materials into bits to be sewn together (for a patchwork quilt) seemed like a futile waste of time." ${ }^{37}$ Some suggest that since Hawaiian gowns (H. holoku) worn by high-ranking women were full-cut rather than tailored like Western dresses, there were no small pieces left over to sew patchwork quilts. Others have queried such utilitarian explanations, rather seeing the innovation as high-ranking Hawaiian women appropriating the "aura and prestige associated with the Western appliqué technique."38

Kamehiro has developed this argument in a sophisticated interpretation of the history of the Hawaiian quilt. She suggests that Kanaka Māoli women early discerned the rarity and the higher value which American women invested in the appliqué technique. In their creation and celebration of this form they invested the quilt with indigenous values of sanctity and rank and with hidden meanings (H. kaona) which reinscribed their mana as high-ranking women. ${ }^{39}$

Design elements and motifs in Hawaiian quilts swiftly changed, privileging local flora and fauna: snowflakes and grapevines were supplanted by breadfruit, coconut and pineapples, pikake (jasmine), lehua (red flower) and tuber rose, dracenas, fish and coral. Sometimes motifs celebrated the perfumed, sensuous appeal of specific locales such as the bombax trees, growing in the grounds of the Queen's Medical Center, in Honolulu. Most Hawaiian quilts have a strong bipolar contrast between layer and ground, at first primarily red on white, blue

35 See Joyce Hammond, Tifaifai and Quilts of Polynesia, Honolulu: University of Hawai'i Press, 1986, Table Two, pp. 38-39.

36 Kamehiro, “Hawaiian quilts," p. 17

37 S. Jones, Hawaiian Quilts, Honolulu: Daughters of Hawai'i, Honolulu Academy of Arts, Mission Houses Museum, 1973, p. 10.

38 Hammond, Tifaifai and Quilts of Polynesia, p. 14; Joyce Hammond, "Polynesian women and tifaefae: fabrications of identity," Journal of American Folklore 99 (1986): 259-79.

39 Kamehiro, "Hawaiian quilts." 
on white or yellow on white and in later decades an expanded palette such as black on yellow or khaki on deep turquoise. Appliqué quilts often have a pronounced symmetry around the central point or navel, the piko $(\mathrm{H}$. which, Kamehiro suggests, refers to Maikoha's navel). Hawaiians distinguish between two types the kapa lau (H. leaf) where a single design is appliquéd and the kapa apana (H.) where two pieces are appliquéd, one centred on the navel and another around the border or lei $(\mathrm{H}$.$) .$

There are several variants of a Hawaiian story which tell of how a Hawaiian woman was inspired to create this new design when the shadow of a breadfruit tree was cast upon her sheet drying on the grass. Kamehiro links this idea of the design as a "shadow" or "silhouette" with the origin story of the paper mulberry tree and with the notion of mana, described by Marshall Sahlins as a divine power, a creative force "which makes invisible things visible." 40 Flows of mana were especially concentrated in the persons of high-ranking people; high chiefs were enjoined to walk around only at night so that their dangerous shadows would not fall on common people and sicken them or require their execution. Aristocratic beauty and efficacy were likened to the rays of the sun, shining brilliantly and creating life from the darkness and chaos of the night (H. po). Clearly missionary tropes about Christianity bringing light into heathen darkness found fertile ground in Hawaiian imaginaries of rank and cosmogony. And some quilts celebrated that other bright light of modernity: the chandeliers which hung in the royal palaces of King Kalākaua and later Queen Lili'uokalani.

Kamehiro highlights how often motifs which celebrate the natural beauties of Hawai'i, were simultaneously affirmations of chiefly power over the fertility of the land. ${ }^{41}$ Many of the flowers imaged were known to be the favourite blossoms of queens and princesses, e.g. the milkwood blossoms or the imported roses growing in the gardens of Queen Lili'uokalani. Emblems of ali'i power abounded and, especially during the reign of the nationalist King Kalākaua (1874-1891), icons of royalty (Figure 37). ${ }^{42}$

Such quilts then were not just benign, sentimental celebrations of Hawaiian nature, but claims to custodianship of place and articulations of Hawaiian sovereignty through celebrations of rank and royalty: for example, the comb of Princess Ka'iulani, her fan and feather plume, and more overt articulations of support for the monarchy in a series of quilts dating from the late nineteenth to early twentieth centuries, imaging the Hawaiian flag, the coat of arms, the crowns

40 Marshall Sahlins, Historical Metaphors and Mythical Realities: Structure in the Early History of the Sandwich Islands Kingdom, Ann Arbor: University of Michigan, 1981, p. 31.

41 Kamehiro, "Hawaiian quilts."

42 Ibid.; Stacey L. Kamehiro, The Arts of Kingship: Hawaiian Art and National Culture of the Kalākaua Era, Honolulu: University of Hawai'i Press, 2009. 
and feather cloaks and feather standards (H. kahili) of Hawaiian royalty. ${ }^{43}$ On occasion flags were imaged upside down to signal the distress and suffering of foreign occupation. Writing was early incorporated to commemorate historical events. And, under the seeming simplicity of symmetrical surfaces, lay kaona (H.) or hidden meanings, often with political import.

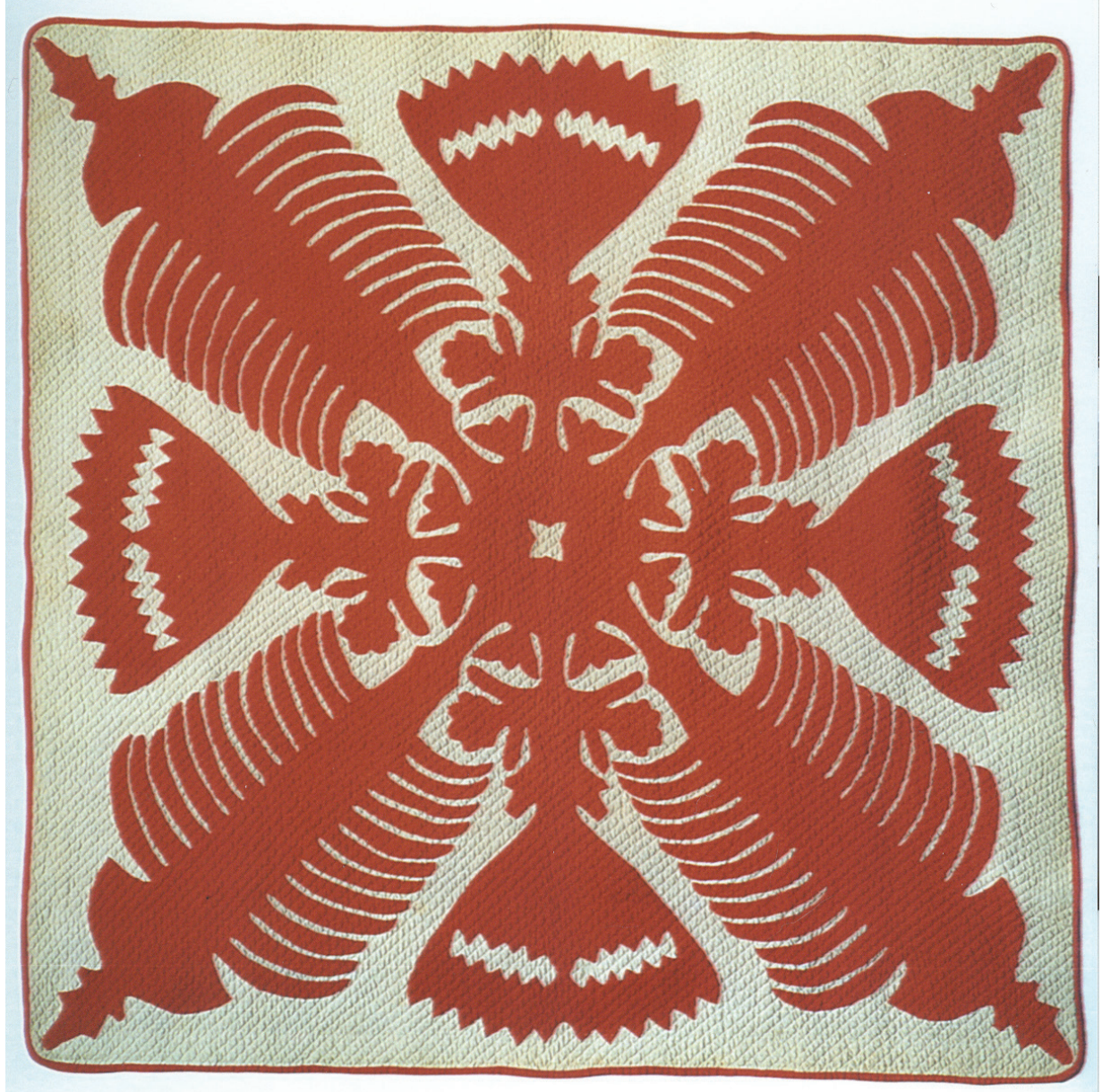

Figure 37. Appliqué quilt (1886) with red design on white background featuring both Hawailan flowers and images of feather standards associated with royalty.

Source: Reiko Mochinaga Brandon and Loretta G.H. Woodard, Hawaiian Quilts: Tradition and Transition, Tokyo: Kokusai Art, 2004, p. 20.

43 Joyce Hammond, "Hawaiian flag quilts: multivalent symbols of a Hawaiian quilt tradition," Hawaiian Journal of History 27 (1993): 1-26. 
Kamehiro suggests that the common image of the sea urchin, evoked associations with an opened eye and the rays of the sun, and thus with aristocratic brilliance in making the invisible visible. ${ }^{44}$ Following Kaeppler, she observes how a series of stacked parallel chevrons mediated by a central line referenced not just the backbone of a sea eel but the seriation of chiefly genealogical succession. ${ }^{45}$ For the most part Hawaiian designs, unlike those from New England, were not rectilinear but curved and arched, imaging crescent moons and rainbows, both strongly associated with chiefly power. The predominant palette also signalled their mana: red for sacred power, yellow for political authority and white, the colour of Lono, the god of rain and fertility.

As Kamehiro notes, Hawaiian quilts were not just generalised evocations of indigenous sanctity and rank but were associated with particular persons and genealogies. ${ }^{46}$ The particular woman who created a new named quilt design had rights to be known as its creator and to prohibit other women from using or stealing that pattern. Although other women collaborated in creating quilts, they could not sit on the basting or the design nor complete the final stitching before the quilt's public display. Quilts were so suffused with the mana of their maker that they were sometimes burnt on her death. Throughout life such valued creations were only rarely used as bed coverings; as with decorated barkcloth it was forbidden to sit or to sleep on such a quilt. They only rarely adorned double beds; less prestigious piecework quilts sufficed for that ${ }^{47}$ They were rather stored in sealed boxes, annually aired, used in display for special occasions and were occasionally offered as extremely valuable gifts at weddings and funerals. Nineteenth-century photographs show Hawaiian royals sitting in front of exquisite quilts and their bodies in death, draped in quilts, as they would have been swathed in barkcloth in the past.

Thus Hawaiian quilts were not so much icons of cosy Christian conjugality but embodied the mana of ali'i nobility and ultimately the monarchy. Rather than a sign of Hawaiian peoples succumbing to the fatal allure of Christian gods and capitalist commodities, Hawaiian quilts might rather be read as appropriations of valued foreign things for indigenous purposes, as a willing and passionate embrace of Christian modernity and even as a resistance to colonial power, especially on the part of high-ranking Hawaiians. Quilts became potent icons of Hawaiian monarchy and anti-colonial resistance particularly in the context of the overthrow of Queen Lili'uokalani by a cartel of American missionaries and businessmen in 1893. As well as signing petitions for the return of the monarchy, as Noenoe Silva has so consummately analysed, Hawaiian women gathered

\footnotetext{
44 Kamehiro, "Hawaiian quilts."

45 Adrienne Kaeppler, Kapa: Hawaiian Barkcloth, Bay: Boom Books, 1980.

46 Kamehiro, "Hawaiian quilts."

47 Reiko Mochinaga Brandon and Loretta G.H. Woodard, Hawaiian Quilts: Tradition and Translation, Honolulu: Honolulu Academy of Arts and University of Hawai'i Press, 2004, p. 18.
} 
around the Queen to create a giant silk patchwork quilt, emblazoned with their names and declarations of loyalty to royalty. ${ }^{48}$ While she was incarcerated in the Iolani palace for ten months after her overthrow in 1893, the Queen and her Ladies in Waiting sewed a "crazy quilt," with irregular shapes and bright colours, and adorned with exquisite embroidery, which in part details the events of those months. It is now known as the "Queen's Quilt" and, as Marata Tamaira has eloquently evoked in a recent paper on contemporary Hawaiian art, is a cherished and potent reminder of American occupation. ${ }^{49}$

Deborah (Kepola) U. Kakalia's stunning gold and purple quilt from 1993, displayed as part of the fifth Asia Pacific Triennial in Brisbane, Australia, titled simply Lili'uokalani evokes the poignant moment of the overthrow a century later, with central images of crowns and feathered standards, and an eight-point star representing Kakalia's husband, all framed by the Queen's favourite flowers of milkwood and her fluttering fans. ${ }^{50}$ This quilt is not just a nostalgic lament for a lost past but an affirmation of sovereignty sentiments in opposition to the United States in a contested present. Curator Maud Page affirms, "Techniques originally taught by American missionaries have been adapted to create inimitable textiles that appear to pulsate." ${ }^{51}$ The pulsation is simultaneously aesthetic and political. The revival of Hawaiian quilt-making in the 1980s-1990s coincided with the reanimation of the Hawaiian sovereignty struggle and a cultural renaissance. As Herda avers, "During the Hawaiian cultural renaissance in the latter half of the $20^{\text {th }}$ century, Hawaiian quilts were embraced as an icon of indigenous culture, just as they had been part of the $19^{\text {th }}$ century's indigenous patriotic expressions of Kanaka Māoli." 52

Yet, as the catalogue of an exhibition mounted in 2002 documents, contemporary quilt-makers include not just women identifying as Kanaka Māoli but those with mixed and foreign ancestry and a Japanese-American man. ${ }^{53}$ The authors of that catalogue insist Hawaiian quilt-making is still a vibrant art. Herda

\footnotetext{
48 Noenoe Silva, Aloha Betrayed: Native Hawaiian Resistance to American Colonialism, Durham: Duke University Press, 2004.

49 Marata Tamarai, “Visual sovereignty and indigenous countervisuality: picturing contemporary Kanaka Māoli art practice in Hawai'i," Ph.D. thesis proposal presentation, Canberra: The Australian National University, 10 April 2012.

50 Maud Page and Ruth McDougall, "Pacific textiles project, Pacific threads," in The $5^{\text {th }}$ Asia-Pacific Triennial of Contemporary Art, ed. Lynne Seear and Suhayana Raffel, Brisbane: Queensland Art Gallery Publishing, 2006, pp. 172-75. See also Margaret Jolly, "The south in southern theory: Antipodean reflections on the Pacific," Australian Humanites Review 44 (2008): 75-100, online: http://epress.anu.edu.au/ahr/044/ pdf/essay05.pdf, accessed 4 July 2014.

51 Ibid., p. 172.

52 Herda, "Hybrid identities and the transference of Hawaiian quilt imagery," p. 19. See also Phyllis S. Herda, "The political nature of quilting in late 19th century Hawai'i," Baessler Archiv 45 (1997): 223-33.

53 Brandon and Woodard, Hawaiian Quilts.
} 
suggests that Hawaiian quilts are now rare and expensive to create and their exhibition in the Honolulu Academy of Arts suggests they are now a high art form for wealthy connoisseurs. ${ }^{54}$

The final rather poignant and perhaps paradoxical chapter in the story of Hawaiian quilts ends in the shopping centres of Ala Moana and Waikiki. Indeed most quilts being sold there as "Hawaiian" are manufactured in the Philippines. Yet the image of the Hawaiian quilt, the shadow of its afterlife perhaps, is everywhere: on T-shirts, pillow slips, coffee mugs, pot holders, coasters, key rings, greeting cards and computer mouse pads. As Herda observes these circulating images of quilts adorn not just the favoured souvenirs of the six million or so tourists who flock to Hawai'i annually but are regularly consumed by locals, Kanaka Māoli and others alike. ${ }^{55}$ Such circulating images of Hawaiian quilts have in Herda's view become signs of a benign even safe "local" identity, far removed from their earlier associations with Christianity, nobility and struggles for sovereignty.

\section{"Mother Hubbards" and aelan dres}

Across Oceania, forms of women's clothing introduced by Christian missionaries have been both satirised and deplored by foreign observers in a lineage from early twentieth-century lady traveller Beatrice Grimshaw to late twentieth-century feminist art historian Griselda Pollock. In Tahiti, Grimshaw described the huge wardrobe of long muslin gowns of her hostess as "night dresses," evoking her "dreamworld" In the Strange South Seas. ${ }^{56}$ Pollock in her critical account of Paul Gauguin was more scathing about "the shapeless sack inflicted on Tahitian women by missionaries." ${ }^{17}$ In a stinging rebuttal of Pollock, Nicholas Thomas writes: "these garments have not been inflicted but adopted by entirely dignified women who had found ways of making ... Christian colonial modernity ... their own." ${ }^{58}$ Most scholars working on clothing in the Pacific over the last decade echo this view, insisting on the agency of Islanders rather than the colonial power of missionary impositions: that introduced clothing was eagerly adopted by Oceanic Christians not inflicted and that these new clothes were not just icons of Christian conversion and signs of a new sexual culture of modesty but

\footnotetext{
54 Herda, "Hybrid identities and the transference of Hawaiian quilt imagery."

55 Ibid.

56 Beatrice Grimshaw, In the Strange South Seas, London: Hutchinson and Co., 1907, pp. 14-15.

57 Griselda Pollock, Avant-Garde Gambits: Gender and the Colour of Art History, London: Thames, 1992, figs 25-26.

58 Nicholas Thomas, "Preface," in The Art of Clothing: A Pacific Experience, ed. Susanne Küchler and Graeme Were, London: UCL Press, 2005, pp. ix-xi, p. ix.
} 
worn as objects of beauty, dignity and power in an embrace of modernity. ${ }^{59}$ But these scholars also suggest rather more complex local stories in the relationship between indigenous and introduced clothing, the gendered and racial salience of such clothes and the way in which women's agency, collectivity, religious and ethnic identity was engaged in the arts of sewing and in wearing these "new clothes." I now focus on some stories from the archipelago of Vanuatu and in particular the work of Lissant Bolton and Maggie Cummings. ${ }^{60}$

But I start with a more personal vignette. During my doctoral fieldwork in South Pentecost, Vanuatu in the 1970s I lived with people who were strenuously anti-Christian, who portrayed their way of life as following kastom (B. the ways of the place) rather than skul (B. Christianity, modernity). ${ }^{61}$ This was daily signalled in their clothes: for women rais (S.), grass skirts they fashioned from ivory pandanus or, for special occasions, lustrous silky banana spathe fibres; for men the pandanus penis wrapper, bipis (S.) plaited from pandanus and dyed with red stripes, tucked up in a bark belt. Women's breasts were bared, men's testicles exposed. And yet when these fervent adherents of kastom crossed the fast flowing river which separated them from their Christian kin at the Catholic mission station of Baie Barrier, they stopped at the hamlet of Sai and changed their clothes, men donning shirts and shorts, women island dresses, in respect of the sartorial codes of their Christian kin. ${ }^{62}$ As a young white woman and, following the advice of a protective supervisor, I routinely wore modest dresses, although my hosts knew I was not a practising Christian. I wore a grass skirt only for major rituals celebrating life crises or elevations of rank. This delighted my hosts but I found it rather uncomfortable, only partly since it chafed my ample hips. A couple of friends and colleagues who visited me in Bunlap village photographed me so dressed but I was wary of such a display of immodesty or "going native" and never dared show such photos to my late father or mother. This was wise since when I gave my father a copy of my book Women of the Place he was visibly shocked by the photos of bare-breasted women and men with penis wrappers with testicles exposed and turned the pages in relief to a photograph of me in a modest T-shirt. ${ }^{63}$ Intriguingly, a later ethnographer and

\footnotetext{
59 Colchester, Clothing the Pacific; Susanne Küchler and Graeme Were (eds), The Art of Clothing: A Pacific Experience, London: UCL Press, 2005.

60 In the conference version of this chapter I also alluded to the cognate arguments of Anna Paini in New Caledonia apropos la robe mission. See Anna Paini, "Rehabiller les symbols: les femmes kanak et la robe mission à Lifou (Nouvelle-Calédonie)," Journal de la Société des Océanistes 117 (2003): 233-53.

61 Skul is now almost obsolete and has been replaced by fasin blong waetman as Christianity has been progressively embraced as part of kastom (by Christians at least) and especially since the period of national independence in 1980.

62 In April 2013 when I walked from the kastom village of Bunlap to the Church of Christ village of Ranwas in South Pentecost, men from Bunlap changed into shorts before entering Ranwas, while women, clad only in rais, remained sitting down on the edges of Ranwas and did not enter.

63 Jolly, Women of the Place, pp. 4, 12.
} 
film-maker in the region, a German man Thorolf Lipp, was not so restrained, wearing the bipis throughout his fieldwork in the 1990s-2000. He says that local men applauded his thus embodying kastom (B.)

I tell this story since it reveals how deeply many of us have imbibed and embodied the associations between nakedness, sexuality and sin in Western imaginaries and according to Webb Keane, a particularly Christian sense of the indexicality of signs, between the outer surface of the body and the inner moral state of the person. ${ }^{64}$ Serge Tcherkézoff has written persuasively about the misrecognitions in early encounters in Tahiti and Samoa such that Europeans saw nakedness when women's breasts were bare, whereas in indigenous opinion they were clothed. ${ }^{65}$ And there is no doubt that the same argument could be made for Vanuatu: there were indigenous codes of respectable clothing which exposed breasts, bottoms and testicles but which Europeans, most consequentially Christian missionaries, saw as "nakedness." How did these contrary codes interact in the process of Christian conversion?

Since the arrival of the London Missionary Society in the southern islands in 1839, Presbyterians who spread from the island of Aneityum in 1848 throughout the southern and central archipelago, the Anglicans in the north from 1849, the Catholics from the 1880s, the Church of Christ and Seventh Day Adventists from the 1920s, and a plethora of new evangelical churches more recently, ni-Vanuatu have become pervasively Christian and, for the most part, well-covered. All denominations urged their converts to adopt the new clothes, although with varying degrees of zealousness. Indigenous clothes are worn only by a tiny minority of those who still adhere to the ancestral religion, or by Christians on rare ritual occasions, in museum displays or for tourists (see below).

Bolton offers an exhaustive overview of indigenous clothing in Vanuatu; I distil only the main contours here. Like the languages and cultures of the archipelago, clothing was regionally diverse. ${ }^{66}$ Men wore either plaited pandanus textile skirts from waist to thigh or passed through their legs, or bark belts with pandanus penis wrappers (B. nambas). Women wore either a "grass" skirt, plaited from pandanus or other fibres, or a plaited pandanus textile passed between their legs or wrapped around their hips. Uniquely in east Santo women wore only a single leaf at the front and a bunch of leaves behind, both suspended from a fibre

64 Webb Keane, “The hazards of new clothes: what signs make possible," in The Art of Clothing: A Pacific Experience, ed. Susanne Küchler and Graeme Were, London: UCL Press, 2005, pp. 1-16.

65 Tcherkézoff, "On cloths, gifts and nudity."

66 Lissant Bolton, "Gender, status and introduced clothing in Vanuatu," in Clothing the Pacific, ed. Chloë Colchester, Oxford and New York: Berg, 2003, pp. 119-39; Bolton, "Dressing for transition: weddings, clothes and change in Vanuatu," in The Art of Clothing: A Pacific Experience, ed. Susanne Küchler and Graeme Were, London: UCL Press, 2005, pp. 19-32; Bolton, “'Island dress that belongs to us all': mission dresses and the innovation of tradition in Vanuatu," in Body Arts and Modernity, ed. Elizabeth Ewart and Michael O'Hanlon, Wantage: Sean Kingston Publishing, 2007, pp. 165-82. 
band. Clothing styles as much as language defined local identities for both niVanuatu and foreign observers, including anthropologists. Early anthropologists like Rivers and Layard distinguished between "mat" and "skirt" cultures, ${ }^{67}$ speculating about their associations with matrilineal and patrilineal descent and the historical sedimentation of cultures. ${ }^{68}$ On Malakula groups were classified as Big or Small Nambas depending on the size of the men's penis wrappers.

As Bolton suggests indigenous "clothing" can be seen as far more than cloth since it included a range of ornamentation and corporeal modification which marked both gender and status: necklaces, ear-rings, bracelets and anklets of shells, fibres and seeds; tattooing, tooth evulsion, nose piercing, head-binding, body painting, coconut oiling and hair-bleaching. ${ }^{69}$ Clothing, ornamentation and body modification was not a matter of individual personal style but tightly specified by collective codes about gender, rank and life course. ${ }^{70}$ So, in Erromango a girl's fibre skirt was lengthened when she was betrothed while widows who were available to remarry shortened theirs. On special ritual occasions Erromangan women wore beautiful decorated barkcloth, trailing to the ground in long streamers when they were married (Figure 38). On Tanna men grew their hair at puberty, bleached it and bound it in long strands which, lengthening with age, signifying enhanced masculinity and seniority. (This hairstyle, remarkably similar to later Jamaican rasta style, was recorded in a drawing by the artist William Hodges on Cook's second voyage). ${ }^{71}$ In the northern islands elevation in rank for both men and women was marked in rituals with body painting and the wearing of leaves like cycas, dracaenas and crotons, or in islands like Ambae more precious, fine and elaborate pandanus textile costumes. These emblems of rank elevation were closely restricted to those who had earned the right to wear them.

As Anna-Karina Hermkens suggests, Christian missionaries not only persuaded people to discard their old clothes but also to eschew such ornamentation and modification of the body (and often collected clothes and artefacts as curios and testaments to "heathen savagery" for museum collections). ${ }^{72}$ Thus as well as "covering up" perceived nakedness there was a desire on the part of both European and Pacific missionaries in Vanuatu to refashion the Christian body.

67 William Halse Rivers, The History of Melanesian Society, two volumes, Cambridge: Cambridge University Press, 1914; John Layard, Stone Men of Malekula, London: Chatto and Windus, 1942.

68 See Haidy Geismar and Anita Herle, Moving Images: John Layard, Fieldwork and Photography on Malakula since 1914, Honolulu: University of Hawai'i Press / Adelaide: Crawford House Publishing, 2009.

69 Bolton, "Gender, status and introduced clothing in Vanuatu." Hermkens (this volume) following Wetherell, suggests that clothing the Maisin people was not such a priority for the Anglicans operating in that region.

70 Bolton, “Gender, status and introduced clothing in Vanuatu," p. 122.

71 See Margaret Jolly, “'Ill-natured comparisons': racism and relativism in European representations of niVanuatu from Cook's second voyage," History and Anthropology 5(3-4) (1992): 331-64.

72 Hermkens "The materiality of missionisation in Collingwood Bay, Papua New Guinea" (this volume). 
The journals, memoirs and magazines of Protestant missionaries in particular are laced with textual and visual exemplars of the "before and after" story of Christian conversion. So in the Presbyterian journal, Quarterly Jottings from The New Hebrides South Sea Islands reports, there are many photographs of recent male converts fully clothed in shirt and trousers, although this may have been only occasional attire worn to please the missionary visitor photographer. ${ }^{73}$ But an anonymous author in that Presbyterian journal makes much of the ironclad association of clothing and Christianity, "Thirty dressed natives carries little meaning to our minds at home. But it should be realised that a savage prides himself on nudity as a badge of heathenism. He needs the courage of conviction to adopt dress. Persecution follows." 74

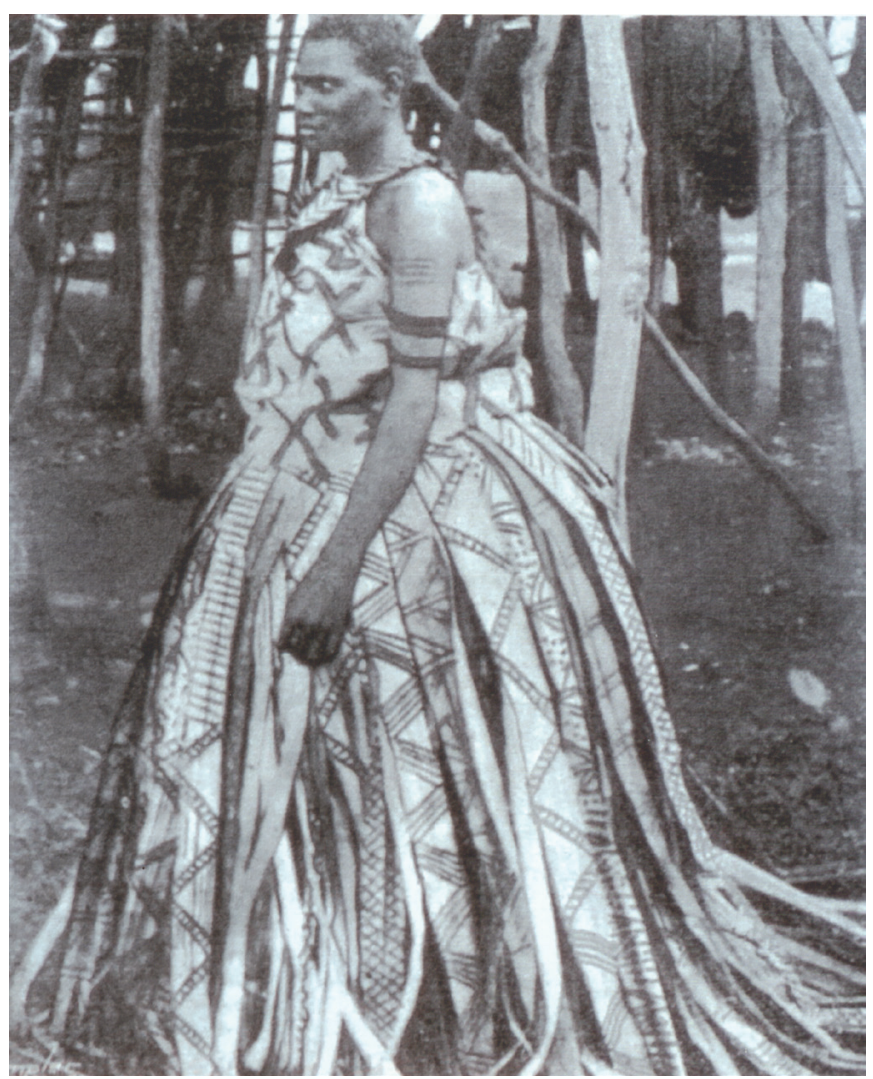

Figure 38. Erromangan woman in a dress of decorated bark cloth, worn on ritual occasions such as marriage, ca. 1880s. Photographer H.A.

Robertson.

Source. H.A. Robertson, Erromanga: The Martyr Isle, London: Hodder and Stoughton, 1903, facing p. 448.

73 Bolton, "Gender, status and introduced clothing in Vanuatu," p. 128.

74 Quarterly Jottings from the New Hebrides, South Sea Islands. 1895-1961, Woodford, England: John G. Paton Mission Fund, 1895, p. 10, cited in Bolton, "Gender, status and introduced clothing in Vanuatu," p. 128. 
Apart from the confident indexicality between clothing and religious conviction, ${ }^{75}$ this imputation of "persecution" from local heathens suggests two opposed camps of clothed converts versus naked savages, but as we know from the broader history of Christianity in the archipelago, conversion could be a slow and fitful process and there was much "backsliding."76 Moreover, introduced clothing was not immediately and exclusively adopted but often worn layered and creolised with indigenous clothes. Here is the Reverend H. A. Robertson writing in Erromanga, The Martyr's Isle (1903):

In their heathen state the men of Aneityum had been dressed like the other New Hebridean savages, if dress it was. The women however, wore and still do wear, skirts made of the pandanus leaf.... These skirts with the addition of a short print jacket, formed a woman's week-day attire; while on Sundays and on all state occasions, a wonderful head gear, in the form of a large barrel shaped bonnet made of plaited pandanus leaf surmounted all. These bonnets were cut into shape and sewed by Esther [the widow of a local man Lazarus who had been an early convert and assistant to the Inglises, a missionary couple]. The hair on the woman's head being thick and woolly, the bonnets were usually worn on their shoulders, the strings being tied securely in front, and the Aneityumese belle thus equipped was, to herself and her admirers, a thing of beauty. The men, as Christians, were clad in shirts and short kilts or lava-lava, no covering being worn on their heads [italics in original, insert mine]. ${ }^{77}$

Creole clothes, which are often satirised by the very missionaries who were trying to change the clothes of ni-Vanuatu, appear in photographs of mission stations and plantations throughout the late nineteenth and early twentieth centuries. Women in the southern islands often wore their fibre skirts over Mother Hubbard-style European dresses as late as the $1940 s,{ }^{78}$ a pattern of layering witnessed in many parts of the Pacific. ${ }^{79}$ By comparison the photographs of the British anthropologist John Layard from 1914 show women at a Catholic mission station on Vao consummately and exclusively clothed in early versions of "island dress" while women of non-Christian villages on Atchin are seen barebreasted but wearing a loincloth and headdress of trade "calico." ${ }^{80}$ Increasingly island dresses became iconic of the good Christian woman. The Presbyterian journal Quarterly Jottings published a description of the preferred style with a wide yoke and puffy elbow sleeves, adorned with red frills and

75 Keane, "The hazards of new clothes."

76 See Margaret Jolly, "Devils, holy spirits and the swollen God: translation, conversion and colonial power in the Marist Mission, Vanuatu, 1887-1934," in Conversion to Modernities: The Globalization of Christianity, ed. Peter Van der Veer, New York: Routledge, 1996, pp. 231-62.

77 H.A. Robertson, Erromanga, The Martyr's Isle, London: Hodder and Stoughton, 1903, pp. 100-01.

78 Bolton, "Gender, status and introduced clothing in Vanuatu."

79 Colchester (ed.), Clothing the Pacific; Jolly, "Of the same cloth."

80 Geismar and Herle, Moving Images, pp. 97, 166 and 294. 
braid: "the natives dearly love bright colours." ${ }^{81}$ The Anglicans in the north rather promoted blouses and skirts and these two dress styles are still seen to distinguish these respective denominations in Vanuatu. ${ }^{82}$

Such dress styles were clearly seen by European missionaries as distinct from their own; their voluminous rather than tailored shape meant an "ordinary native dress" was "something like a lady's nightdress." ${ }^{83}$ Although we might perceive racialisation in the missionary promotion of this form of dress, ni-Vanuatu Christian women, in both villages and towns, "grassroots" and elite women, up to and beyond national independence in 1980 seemed to eagerly embrace the sewing and wearing of such dresses. Bolton's several publications on aelan dres (B.), associated workshops with women fieldworkers at the Vanuatu Cultural Centre and a film on the subject evince the pleasure and pride of women in such dresses. Details such as the colours and patterns of cloth, the addition of "wings" or "ears" at the side, the quality and abundance of lace and braid on the bodice mark the island, the denomination and even the village of origin. And collectively aelan dres also came to be seen as a generic national dress. ${ }^{84}$ The generation of women who lived through the struggle for independence from the conjoint colonisers, Britain and France, were urged to see it as iconic not just of their Christianity but their nationality. Like the Hawaiian quilt, a material form which was introduced as part of a colonially and racially inflected Christianity, aelan dres has been appropriated as indigenous. But significantly there is no marked masculine counterpart, ${ }^{85}$ an asymmetry which might occasion more reflection.

Bolton has both explored and animated the revival of indigenous forms of cloth, and especially the pandanus textiles of Ambae. ${ }^{86}$ These textiles are being made and worn by women on important occasions such as life crisis and grade-taking rituals, although often with bras and some layers of cloth. They signal a new phase in the creolisation of clothes, a new and visible conjunction of kastom and Christianity. And in the sequestered context of the Vanuatu Cultural Centre and its museum in August 2006, at the conclusion of the Women's Filwoka Workshop led by Jean Tarisesei and Lissant Bolton I was the privileged witness to a number

\footnotetext{
81 Quarterly Jottings, 1896, p. 7.

82 Bolton, "Gender, status and introduced clothing in Vanuatu"; Bolton, "'Island dress that belongs to us all."

83 Quarterly Jottings, 1896, p. 7.

84 Bolton, "Gender, status and introduced clothing in Vanuatu"; Bolton, "Island dress that belongs to us all."'

85 See Bruce Knauft, "From self-decoration to self-fashioning: orientalism as backward progress among the Gebusi of Papua New Guinea," in Body Arts and Modernity, ed. Elizabeth Ewart and Michael O'Hanlon, Wantage: Sean Kingston Publishing, 2007, pp. 88-107.

86 For example see Bolton, "Gender, status and introduced clothing in Vanuatu." For an appraisal see Jolly, "Material and immaterial relations."
} 
of older women filwokas, the vast majority of whom were practising Christians, daring to bare their bodies in a public fashion parade of what kastom dres blong yumi (our indigenous dress) looked like. ${ }^{87}$

\section{Trouble with traosis}

As Bolton acknowledges and Maggie Cummings documents in detail, not all niVanuatu women are comfortable with aelan dres. ${ }^{88}$ Younger women and especially those in urban centres like Port Vila and Santo are rejecting this style of dress as old-fashioned and uncomfortable. Maggie Cummings quotes many younger women who prefer more tailored clothes, shorter dresses and even traosis (B. loose wide pants like culottes or surf shorts). ${ }^{89}$ They see the aelan dres as hot and oppressive and suggest they would only wear it to hide a pregnancy or when they were married and became a mother. Traosis are especially celebrated as comfortable, but as in many parts of the western Pacific have become the subject of fierce debate. ${ }^{90}$ Opponents say, since traosis show the contours of the body they are immodest and thus invite rape and violence from men, or that such women are usurping the right of men to wear the trousers. Cummings' young women interlocutors retort that they can run faster from men's unwanted sexual advances in trousers and that they offer a layer of protection from rape. They even suggested that voluminous island dresses which billow in the wind made them feel naked. Yet, on several islands of Vanuatu, such as Paama, chiefs have banned women from wearing trousers in public places in the last decade. Such bans have been supported by some older Christian women's groups but denounced by NGOs like Amnesty International who have suggested to the UN that such bans, like associated bans on women's mobility, constitute a denial of a basic constitutional freedom and of women's universal human rights.

More than pleasure and national pride are involved in this sartorial struggle. In their desires to "look good," young women are not just embroiled in debates about local fashions in a global world of consumption but a moral and political economy about clothing which associates modest dress and comportment with

\footnotetext{
87 Maggie Cummings, "Looking good: the cultural politics of island dress for young women in Vanuatu," in The Contemporary Pacific 25(1) (January 2013): 33-65, makes an important distinction between this concept and stret fasin blong dresap, "the proper way to dress."

88 Bolton, "Gender, status and introduced clothing in Vanuatu," p. 36; Bolton, "“Island dress that belongs to us all," p. 177; and Maggie Cummings, "The trouble with trousers: gossip, kastom and sexual culture in Vanuatu," in Making Sense of AIDS: Culture, Sexuality and Power in Melanesia, ed. Leslie Butt and Richard Eves, Honolulu. University of Hawai'i Press, 2008, pp. 133-14; Cummings, "Looking good."

89 Cummings, "The trouble with trousers"; and Cummings, "Looking good."

90 See Deborah McDougall, "Fellowship and citizenship as models of national community: United Church Women's Fellowship in Ranongga, Solomon Islands," Oceania 74(1-2) (2003): 61-80; Martha Macintyre, "Police and thieves, gunmen and drunks: problems with men and problems with society in Papua New Guinea," The Australian Journal of Anthropology 19 (2008): 179-93.
} 
women's sexual virtue. ${ }^{91}$ In choosing not to wear aelan dres young women say they invite violent retribution from men, including from jealous boyfriends and controlling husbands, and severe criticism from older women. Bolton herself reports the case of a woman from Pentecost who married a man and lived in Port Vila, but refused to wear the aelan dres characteristic of his island. ${ }^{92} \mathrm{He}$ subjected her to violent abuse and a kastom court (community hearing) which ordered her to pay a fine on several occasions. But she persisted in wearing her preferred jeans.

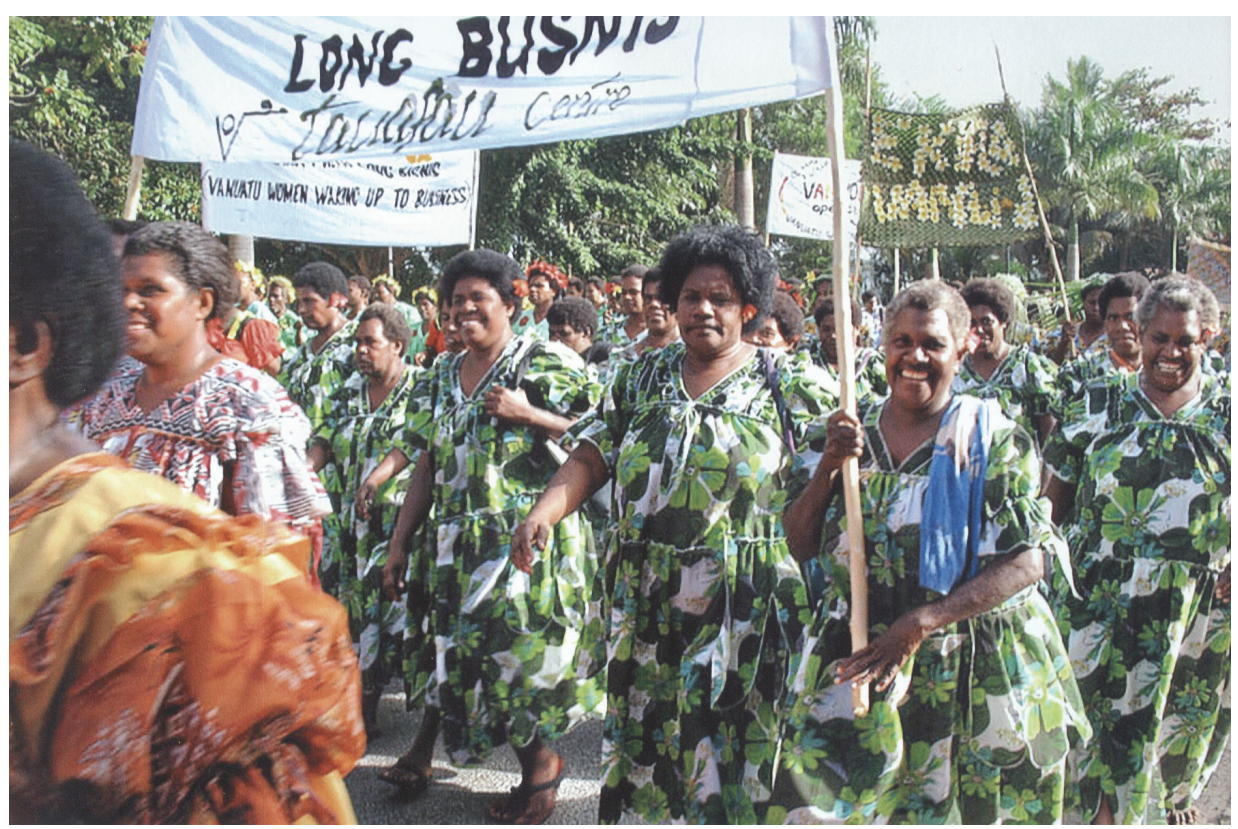

Figure 39. Ni-Vanuatu women marching together on the streets of Port Vila wearing identical aelan dres to celebrate women in business, July 2009.

Source. “Open Day 2009," VANWODS Microfinance, 17 July 2009, online: http://microfinance.vanessasuen. com/2009/07/open-day-2009, accessed 5 August 2013.

It would be hard to deny that notions of rispek (B. respect) and sexual modesty are at play here, along with notions about the right of men and of maledominated kastom courts to control women's comportment, clothing and sexual behaviour. Such adjudications simultaneously engage kastom and Christian values in reinscribing patterns of male control. Yet increasingly younger women are resisting such imputations and adjudications and wearing what "looks good." As Cummings suggests, "looking good is both an aesthetic and a moral

91 Cummings “Looking good," 2013

92 Bolton, “'Island dress that belongs to us all,"” p. 177 
imperative." ${ }^{93}$ So even though older ni-Vanuatu women and some scholars have insisted that the wearing of aelan dres is primarily about women's collective pleasure and religious and ethnic identity rather than about Christian sexual modesty and shame (Figure 39), the spurning of such dress styles by younger women might suggest that it is not a question of either / or but of both / and.

\section{Some missing threads?}

Scholarly approaches to Christianity in Oceania have lurched between the clichéd polarities of treating Pacific peoples as victims of the colonial power with which Christianity was palpably if tensely articulated ${ }^{94}$ and seeing them as eager agents embracing new gods and foreign goods. ${ }^{95}$ The history of cloth has been an integral part of such narratives. For too long the adoption of Western clothes and women's sewing classes were seen simply as part of a colonially imposed discipline of domesticity. Over the last decade scholars have consummately queried such verdicts stressing the indigenous agency at work in acts of appropriation, translation and transformation of cloth and clothing. As we have seen the histories of both the Hawaiian quilt and of aelan dres are imbued with Oceanic meanings and values which often go unappreciated by the casual observer.

Yet in our discursive stress on indigenous agency and appropriation it is important not to completely lose sight of the colonial power and capitalist modernity which was part of the saturated "light" of Christianity as it penetrated "heathen darkness," nor the way in which novel Christian values about "sexuality" which associated bared bodies with sin, which indexically connected the surface of the body and the inner person or the "soul" were internalised by generations of Pacific peoples. ${ }^{96}$ Hawai'i and Vanuatu are places where Christianity has so long prevailed that it is now seen as an inherent aspect of indigenous culture. But in the high valleys of Papua New Guinea (PNG) evangelical Christianity has only recently triumphed. Here sexual cultures characterised by secret male initiation, the insemination of boys and gendered segregation have been supplanted by companionate heterosexual marriage, greater female autonomy and perceptions of homosexuality as a foreign import only in the decades since the 1970 s. ${ }^{97}$ Some ethnographers of PNG are reporting a sense of "humiliation" about past

\footnotetext{
93 Cummings, "Looking good," p. 34.

94 For example see Roger M. Keesing, Custom and Confrontation: The Kwaio Struggle for Cultural Autonomy, Chicago: University of Chicago Press, 1992.

95 For example see Joel Robbins, Becoming Sinners: Christianity and Moral Torment in a Papua New Guinea Society, Berkeley: University of California Press, 2004.

96 Keane, "The hazards of new clothes."

97 Gilbert Herdt, "From ritual sex to sexual individuality: tradition and modernity in Sambia sexual culture," Public lecture, Canberra: The Australian National University, 11 July 2012.
} 
practices or a state of "moral torment" among Christians. ${ }^{98}$ Gilbert Herdt has recently spoken of denial, shame and even "aphasia" about past sexual cultures among the Sambia given the force of the novel Christian fabric of "sexuality," as married women and men nestle down under one blanket. ${ }^{99}$ Holly Wardlow rather evokes the continuing struggle and self-discipline of Christian couples living and sleeping together. ${ }^{100}$

Foreign Christian missionaries too often assumed the binaries of naked heathens and clothed Christians clearly distinguished sexual lasciviousness from chastity and modesty. Yet diverse indigenous patterns of clothing were never indexical of sexual cultures. Women's grass skirts and men's penis wrappers were dignified forms of dress in sexual cultures which practised long periods of heterosexual abstinence (as in South Pentecost, Vanuatu) ${ }^{101}$ or where heterosexual relations were suffused with anxious fears of mutual pollution (as in parts of Highlands PNG). Women's breasts might be routinely exposed in a culture where female virginity was sacralised but then ritually deflowered, as in Samoa. And the clothing introduced by Christian missionaries was surely no guarantor of greater sexual modesty or monogamy. As Webb Keane has suggested in his brilliant essay "The Hazards of New Clothes":

Herein lies a persistent tension in missionary efforts to clothe the naked. For in covering our nakedness and directing attention to our artificial surface, clothing threatens to supplant us. Mission history across the colonial world shows a persistent and troubling tension between the hope that clothing will change people, and the danger that people once clad will invest their clothing with too great a significance. ${ }^{102}$

He situates this tension in the strenuous efforts by Christian moderns and especially Protestants to radically distinguish persons and things, subjects and objects and thereby to extinguish the animated materiality, the sensuous embodiment of cloth which characterised ancestral religions. ${ }^{103}$

But, he does not and we cannot say that these "new clothes" had nothing to do with new Christian values about sexuality, bodily comportment and

\footnotetext{
98 Joel Robbins and Holly Wardlow (eds), The Making of Global and Local Modernities in Melanesia: Humiliation, Transformation and the Nature of Cultural Change, Aldershot: Ashgate, 2005; Robbins, Becoming Sinners; Wardlow, Wayward Women.

99 Gilbert Herdt, "From ritual sex to sexual individuality"; see Wardlow, Wayward Women; Wardlow, "Paradoxical intimacies," (this volume).

100 Wardlow, "Paradoxical intimacies," (this volume).

101 See Margaret Jolly, "Damming the rivers of milk? Fertility, sexuality and modernity in Melanesia and Amazonia," in Gender in Amazonia and Melanesia: An Exploration of the Comparative Method, ed. Tom Gregor and Donald Tuzin, Berkeley: University of California Press, 2001, pp. 175-206.

102 Keane, "The hazards of new clothes," p. 3.

103 Webb Keane, Christian Moderns: Freedom and Fetish in the Mission Encounter, Berkeley: University of California Press, 2007.
} 
domesticity. The Hawaiian quilt may have been appropriated enthusiastically and imbued with the values of indigenous sanctity and rank, but practices of royal incest and the Hawaiian hula were abandoned (but the latter revived) and the chants which celebrated the sexual organs of the ali'i nui, their virility and fertility, gave way to Christian hymns praising Jehovah's creation. The fabric of the aelan dres may now be imbued with women's pleasures and collective ethnic and national identities, but it also signals sexual modesty, gendered rispek and the crucial significance of being a married mother. The repressive control and sexual violence experienced by some young women who prefer not to wear it should make us pause.

There is a tendency for either/or explanations of Oceanic cloth which perhaps unduly associate indigenous values and things with continuity and agency and exogenous values and things with rupture and oppression. We need to get beyond these ideologically charged antinomies and pursue a both/and approach. I have advocated the writing of a history of Oceanic cloth which is "saturated." This is not just a metaphoric play with "Oceanic," suggesting clothes which are soaked, but imagines a cloth which is imbued with both indigenous and exogenous values, impregnated with continuity and rupture and saturated with ongoing struggles about embodied gendered persons and sensuous, beautiful things. 
This text taken from Divine Domesticities: Christian paradoxes in Asia and the Pacific, edited by Hyaeweol Choi and Margaret Jolly, published 2014 by ANU Press, The Australian National University, Canberra, Australia. 